\title{
PROJECTION ANALYSIS FOR CADASTRAL MAPPING
}

\author{
Analise da projeção para mapeamento cadastral \\ GOPIKRISHNAN.T ${ }^{1}$ \\ RAMAKRISHNAN.S.S ${ }^{2}$ \\ ${ }^{1}$ Assistant Professor, AMS College of Engineering, Muthapudupet, \\ Chennai - 600055 \\ ${ }^{2}$ Professor, Institute of Remote Sensing, Anna University, Chennai - 600025 \\ E-mail: gktphd@gmail.com
}

\begin{abstract}
Maps are created for different purposes. Among the various types of maps, cadastral maps are created by cadastral surveying. Cadastral maps are used for management of land and land-related activities by Government organisations or other institutions in various countries. Cadastral map making is both an art and a science, and the data about a surveyed land parcel are collected and incorporated in cadastral maps. Technological development has resulted in the development of simple methods for cadastral mapping. The Indian cadastral system for the state of Tamil Nadu is described in this paper. The challenges of conversion while scanning conventional paper-based land records to make digital records are explained. The procedure for selecting an appropriate projection system for scanned digital conventional records is elaborated on. A statistical application for identifying the nature of the data is shown. An inverse ranking system is used to identify a suitable projection system. Projection research is important in cadastral mapping when digitally processing a large number of land records in a country. The described method is effective for identification of a suitable projection system.
\end{abstract}

Keywords: Cadastre; Conventional and Modern Survey; Projections.

\section{RESUMO}

Mapas dão evidências ao desenvolvimento da civilização neste mundo, os quais são criados para muitos propósitos. Entre os vários tipos de mapas, os mapas cadastrais são criados para estudos cadastrais e são úteis para o gerenciamento do uso da ocupação da terra e as atividades a ela relacionadas por organizações governamentais ou institucionais dos países. A elaboração de maps cadastrais é uma arte e uma ciência onde vários dados a respeito dos lotes de terreno são coletados, 
estudados e incorporados aos mapas cadastrais. O desenvolvimento tecnológico facilitou as maneiras de produzir mapas cadastrais. O sitema cadastral da India, no estado Tamil Nadu, é apresentado nesta pesquisa. Os desafios da conversão digital a partir de documentos convencionais baseados em dados do terreno para dados digitais são trabalhados. Os desafios da conversao de documentos analógicos de registro da terra para dados digitais são explicados. Apresenta-se o procedimento para selecionar um sistema de projeção adequado a partir dos dados dos registros escanerizados. Foi realizada uma análise estatística para identificar a natureza dos dados, bem como um sistema de classificação para identificar a projeção mais adequada. A pesquisa sobre a projeção cartográfica é importante quando se realiza o processamento digital de um grande numero de registros de terra em um determinado pais. O método descrito é efetivo na identificação de uma sistema de projeçao.

Palavras-chave: Cadastro; Levantamento Moderno e Convencional; Projeções.

\section{INTRODUCTION}

Maps demonstrate the development of civilisation in the world. There are many types of information that can be obtained from a map. Types of maps include road maps, rail network maps, air route maps, town maps, city maps, district maps, state maps and maps of various countries. A map is a pictorial representation of a large area in small scale. Among various types of maps, cadastral maps are created by cadastral surveying. Cadastral maps are used for land management-related activities in many countries because they show land details. Proper land management is important because poor land management leads to encroachments (KRISHNAN and RAMAKRISHNAN, 2012). Management and maintenance of land are based on land records and land management laws.

Land management laws in many countries use the categories classified by Sir Robert Richard Torrens. The Torrens classification system includes both positive and negative modes. A positive mode allows a person to claim ownership of land that he or she owns. The negative mode allows a person to pay taxes to the government, but he or she cannot claim ownership of the land. Vacant site taxes, building taxes, farming taxes and agricultural taxes may be collected from citizens of the country. Taxes are collected based on the cadastral information available to government organisation via cadastral maps (EASSIE et al, 2004).

Cadastral maps can be used as a means to summarise information about all of the land in a country. Information needed for taxing land includes ownership, the area owned, the type of use, and the geographical location. Taxes are finalised by the governments of a country based on information in cadastral maps. An important aspect of cadastral maps is to preserve the accuracy and precision of the areas of land parcels. Cadastral mapping requires a projection that should be suitable for analysis. Projections can fit a cadastral map to the curved earth surface with minimal errors. The Earth is actually an irregular mass revolving around sun in an elliptical orbit. The earth surface is also irregular, but is approximately spherical. 
The Earth's surface is assumed to be approximately a spheroid or ellipsoid. The shape of earth is important for studying earth and the astronomical or celestial bodies around it. The shape of the Earth affects cadastral mapping on a large scale. Cadastral mapping with a chain survey considers the Earth to be flat. If a chain surveyed area is larger than 250 square kilometres, the curvature of the Earth should be considered for calculating areas and determining land dimensions, as recommended by American Survey Institute (KANETKAR, 1994).

If a curved Earth surface is considered for cadastral mapping, the map will have to have distortions. Distortion possibilities for a map include shapes, areas, distances and directions. Distortions can be minimised based on the map requirements. However, limiting area distortions is vital for cadastral mapping.

Cadastral mapping and surveying was started during the period when the British ruled in India. Cadastral maps from the British period are in use today as base maps. A cadastral survey is conducted by chain surveying. A chain survey is performed using the Diagonal and Offset method. Cadastral maps created using a chain survey should be projected using mapping software for analysis. Chain survey-created cadastral maps are called conventional cadastral maps or conventional land records.

This paper describes a method for selecting suitable or appropriate projections for conventional cadastral maps. Detailed explanations of conventional land records with suitable diagrams are provided.

\section{CONVENTIONAL LAND RECORDS}

Conventional land records are paper based and created by the Diagonal and Offset method (KANETKAR, 1994). The method has been used since the period of British rule in India. The method was found to be reliable and precise at the time. The Diagonal and Offset method using chain survey is still used for land surveying. Land parcels in a village are grouped together as five acres of wet land parcels and ten acres of dry land parcels. Grouped wet land and dry land parcels are then used to form condoms irrespective of ownership of those parcels. A village will have more than two condoms. The condom boundaries will be set by use of a 20 ” theodolite for angular measurement and a chain survey for linear boundary measurement.

Condoms are divided on the basis of land parcels with survey numbers unique for every village. Divided land parcels are surveyed by the Diagonal and Offset method using a chain and a cross staff. The Diagonal and Offset method is shown in Figure 1. Diagonal lines passing through the entire length of a parcel are selected and named as base lines. Perpendicular offsets are formed at right angles to the base lines. Perpendicular offsets connect straight parcel boundary edges from the base lines and are marked using a wooden cross staff.

Offsetting land parcels produces smaller areas shaped as right triangles and trapezoids. The trapezoids will be further subdivided into sub-offsets to form rectangles and right angle triangles. The area then will be calculated from formulas for right triangles and rectangles, with the total parcel area determined by summing 
the individual areas. The area of a land parcel is then plotted on paper, with the Parcel based land records compiled as field measurement books. Individual parcel land records are plotted together as village maps with physical markings on the land shown by village boundary stones. The boundary stones of individual parcels do not have carvings on their top surfaces.

Figure 1 Showing Diagonal and Offset method.

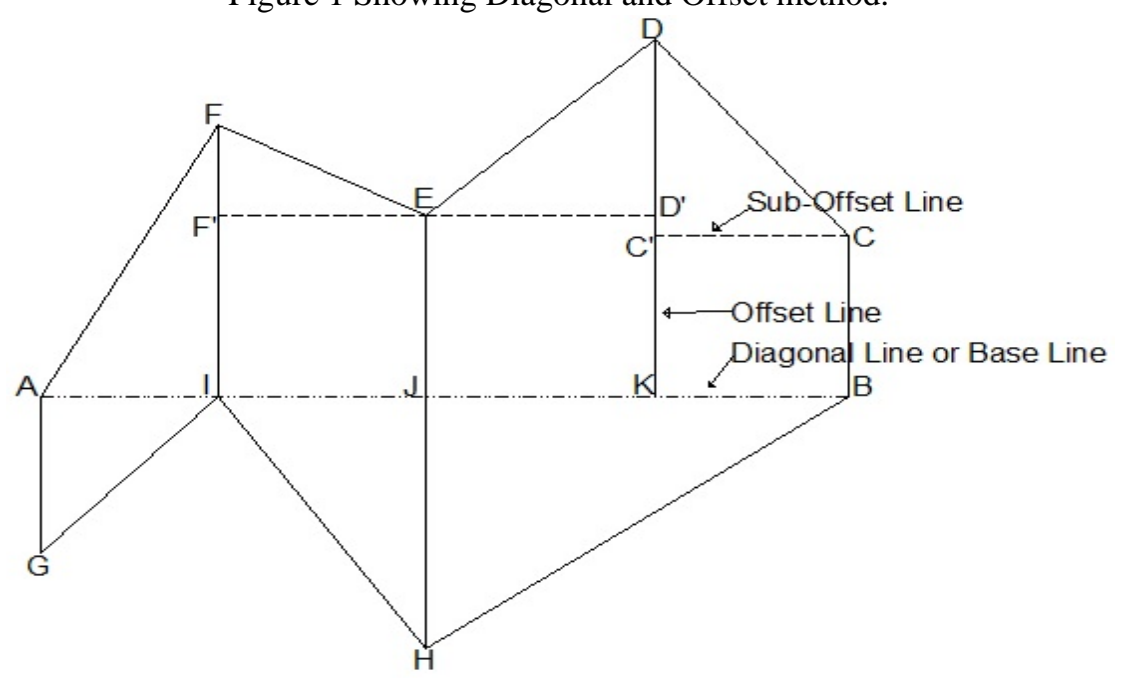

The boundaries of a village will be marked with village boundary stones. The village boundary stones will be accompanied by condom boundary stones and parcel boundary stones. There will be different carvings on top of village and condom boundary stones. Village boundary stones will be shared by adjacent villages and will have demarcations showing if the boundary is a Bi-Junction or a Tri-Junction. If the village boundary is shared by two villages then the boundary is indicated by a Bi-Junction stones, while a boundary or point shared by three villages is shown by a Tri-Junction stone.

Boundaries stones used for demarcation of village and condom boundaries are quarry-cut rectangular stones with approximate square cross sectional area. Boundary stones are chiselled roughly on all sides, so smooth surface may not be available. Possible village boundary stone carvings that would be on the top side of stones are illustrated in Figure 2. Figure 3 shows field photographs of stones. Boundary stones are fixed on land based on precise survey measurements. However, even with precise survey measurements, errors can propagate in land surveying. Land survey errors must be limited to ensure quality land records. Land survey error limitations are referred to as error allowances. Land survey error allowances for chain surveys are called conventional survey error allowances. 
Figure 2 Bi-junction, Tri-junction and condom boundary stones.
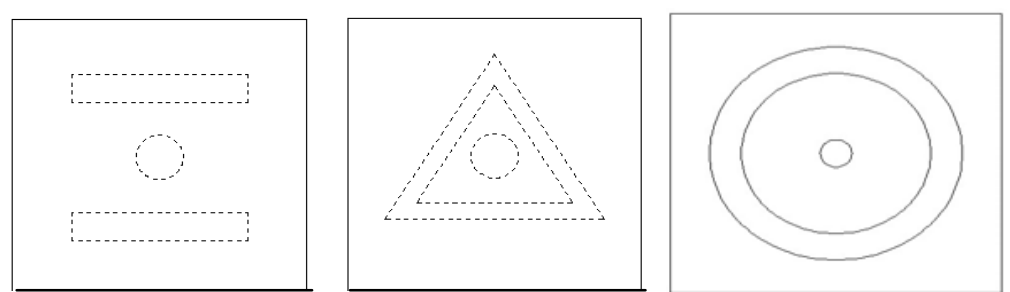

Figure 3 Field photos of Bi-junction, Tri-junction and condom boundary stones.

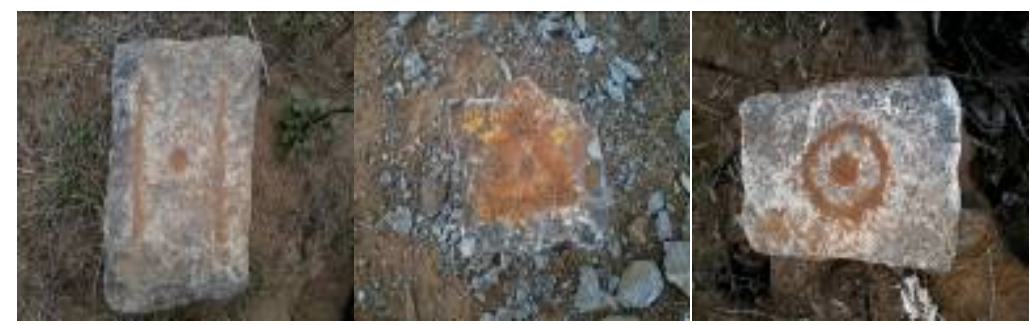

\subsection{Conventional Survey Error Allowance}

Conventional survey error allowances were started during the British rule in India. At present, the rules are being amended for the Survey and Land Records Department of Tamil Nadu. The allowances for surveying using metric chains by the Diagonal and Offset method are one link for one chain measurement i.e., $\pm 1 / 100^{\text {th }}$ unit of chain. The value of one link in a $20 \mathrm{~m}$ chain is $20 \mathrm{~cm}$. Standard chain lengths according to Indian standards are $5 \mathrm{~m}, 10 \mathrm{~m}, 20 \mathrm{~m}$, and $30 \mathrm{~m}$, so the link size varies with respect to different chains. Area measurements can have variations of $\pm 5 \%$ by use of chain surveys using the Diagonal and Offset method. Chain surveyed land records have been found to conflict with the Total Station surveyed land record of the same land parcel.

Conflicts of linear boundary distances and areas can be readily identified in records. However, the Total Station surveyed land record is then assumed to be accurate. The Total Station survey for a selected village is used to aid in the selection of a suitable projection. A suitable projection is selected by comparing areas from land parcels surveyed by conventional means and the Total Station surveyed land records from the same village. The selection of a suitable projection is performed using an inverse ranking system and statistical analysis as explained below.

\section{METHODOLOGY}

The major objective of this paper is to find a suitable projection system. A suitable projection system should project old conventional land records with 
minimal adjustment and errors. The selection of a suitable projection system involves a pilot study of a village. Based on the results of the pilot study, conclusions about a suitable land record projection system can be reached. The first steps toward determining a suitable land record projection system is to collect land records or cadastral maps.

Paper-based land records or cadastral maps are collected for villages in Ambattur taluk from the Tamil Nadu Survey and Land Records Department. The Ambattur taluk map is used to select one village based on topography that is similar to other villages. The villages with a large number of undulations, such as hillocks and hills, are avoided because the land records of those villages are difficult to match in an orthographic view. Because distance measurements in land records or cadastral maps will include surface slope lengths, we need the orthographic distance for mapping. Cadastral maps or land records show village boundary stone locations.

Village boundary stones are identified in the pilot study village. Stones that are open to the sky or have fewer obstructions are selected. Selected village boundary stones are used for a global positioning system survey. A global positioning system survey provides latitude and longitude. Latitude and longitude are then converted to projected coordinate system coordinates. The projected coordinate system provides coordinates for the Total Station survey. The Total Station survey uses coordinates expressed in metres or feet. Coordinates for the Total Station survey are obtained from the village boundary stones that are used for the global positioning system survey.

The locations of village boundary stones where the global positioning system survey is carried out are utilised as the main stations for the Total Station survey. The main stations of the Total Station survey are used for surveying individual plots in the pilot study village. The Total Station survey is coordinate based, with the production of east and north coordinates. The coordinates are also called local coordinates, which are based on latitude and longitude. The local coordinate database is created and plotted using Auto-Cad software. The coordinate data base is used to create a map of the pilot study village. The pilot study village area obtained by Total Station surveying is assumed to be accurate or the true area of the land parcels. Total Station surveys have errors that are negligible compared to the Chain surveyed land records. The chain surveyed land records of the pilot study village are compared with the Total Station survey map of the pilot study village.

The pilot study village map is collected from the Tamil Nadu Survey and the Land Records Department and was georeferenced with geographical information system software. The pilot study village map is converted to a digital form by scanning to raster format. The raster format pilot study village map area of each land parcel is traced out by digitisation. By digitisation polygons similar to village parcels are created. Areas of polygons in the pilot study village are calculated after projecting into five different projected coordinate system map projections. The projected coordinate map projections used in this research are Everest $1880 \mathrm{IV}$, WGS 1984-44N, Albers Equal Area South Asia Conic, Cylindrical Equal Area, and 
Cylindrical Equal Area (WGS-1984). The Everest 1880 IV is based on the Everest Projection, while WGS $1984-44 \mathrm{~N}$ is based on an ellipsoid where $44 \mathrm{~N}$ indicates the zone in which Tamil Nadu lies, The Albers Equal Area South Asia Conic is based on a conic projection for South Asia, the Cylindrical Equal Area is based on a cylindrical projection based on spheroid and the Cylindrical equal area (WGS-1984) is based on a cylindrical projection based on the ellipsoid WGS 1984.

The purpose of using five different projections other than a cartographic projection is that there is no specific projection created for cadastral and cartographic application based on conformal standards. The projections employed in this research that are equivalent to conformal are WGS $1984-44 \mathrm{~N}$ and the Albers Equal Area South Asia Conic (SNYDER, 1987).

Five different projections are used to project digitised land parcels, which results in different areas for given polygons in different projections. The area obtained by a Total Station survey of the pilot study village and the areas obtained in different projections of the pilot study village is compared. The projection that results in an area with the smallest error is identified as suitable. A suitable projection system is finally selected by an inverse ranking method and statistical analysis.

The inverse ranking method entails assigning values from one to five to the projections based on the ascending order of accuracy. The projection with the least error when compared with the Total Station survey area is assigned a value of one. The projection with the next smallest error when compared with the Total Station survey area is assigned a value of two and so on. By inverse ranking, the projection with lowest rank total has the least error when compared to other projections. The projection that was found to be most suitable according to the inverse ranking method was the Cylindrical Equal Area, which is based on a spheroid. The inverse ranking method is shown in Table 1 . The areas of the individual parcels that were used for the inverse ranking are subjected to statistical analysis.

Table 1 - Inverse rank to projections based on area.

\begin{tabular}{|c|c|c|c|c|c|}
\hline Parcel ID & $44 \mathrm{~N}$ & 80 & AEAC & CEA & CEA84 \\
\hline 1 & 4 & 5 & 2 & 1 & 3 \\
\hline 2 & 4 & 5 & 2 & 1 & 3 \\
\hline 3 & 2 & 1 & 3 & 5 & 4 \\
\hline 4 & 3 & 4 & 2 & 1 & 2 \\
\hline 5 & 4 & 5 & 2 & 1 & 2 \\
\hline 6 & 4 & 5 & 2 & 1 & 3 \\
\hline 7 & 1 & 3 & 2 & 4 & 2 \\
\hline 8 & 3 & 4 & 2 & 1 & 2 \\
\hline 9 & 4 & 5 & 3 & 1 & 2 \\
\hline 10 & 4 & 1 & 2 & 5 & 3 \\
\hline 11 & 4 & 5 & 3 & 1 & 3 \\
\hline 12 & 3 & 4 & 2 & 1 & 2 \\
\hline 13 & 2 & 1 & 3 & 4 & 3 \\
\hline 14 & 4 & 5 & 3 & 1 & 2 \\
\hline
\end{tabular}

Bol. Ciênc. Geod., sec. Artigos, Curitiba, v. 19, nº 4, p.729-745, out-dez, 2013. 


\begin{tabular}{|c|c|c|c|c|c|}
\hline 15 & 4 & 5 & 3 & 1 & 2 \\
\hline 16 & 2 & 1 & 3 & 5 & 4 \\
\hline 17 & 2 & 1 & 3 & 5 & 4 \\
\hline 18 & 2 & 1 & 4 & 5 & 3 \\
\hline 19 & 2 & 1 & 4 & 5 & 3 \\
\hline 20 & 2 & 1 & 3 & 5 & 4 \\
\hline 21 & 4 & 5 & 2 & 1 & 3 \\
\hline 22 & 4 & 5 & 2 & 1 & 3 \\
\hline 23 & 3 & 4 & 2 & 1 & 2 \\
\hline 24 & 2 & 1 & 4 & 5 & 3 \\
\hline 25 & 4 & 5 & 2 & 1 & 3 \\
\hline 26 & 2 & 1 & 4 & 5 & 3 \\
\hline 27 & 4 & 5 & 3 & 1 & 2 \\
\hline 28 & 4 & 5 & 3 & 1 & 2 \\
\hline 29 & 4 & 5 & 2 & 1 & 3 \\
\hline 30 & 3 & 4 & 2 & 1 & 2 \\
\hline 31 & 2 & 1 & 3 & 5 & 4 \\
\hline 32 & 4 & 5 & 3 & 1 & 2 \\
\hline 33 & 4 & 5 & 2 & 1 & 3 \\
\hline 34 & 2 & 1 & 3 & 4 & 3 \\
\hline 35 & 1 & 2 & 4 & 5 & 3 \\
\hline 36 & 2 & 1 & 3 & 5 & 4 \\
\hline 37 & 4 & 5 & 2 & 1 & 3 \\
\hline 38 & 2 & 1 & 3 & 5 & 4 \\
\hline 39 & 2 & 1 & 3 & 4 & 3 \\
\hline 40 & 2 & 1 & 3 & 4 & 3 \\
\hline 41 & 4 & 5 & 2 & 1 & 3 \\
\hline 42 & 2 & 1 & 3 & 5 & 4 \\
\hline 43 & 4 & 5 & 2 & 1 & 3 \\
\hline 44 & 3 & 4 & 2 & 1 & 2 \\
\hline 45 & 2 & 1 & 3 & 5 & 4 \\
\hline 46 & 4 & 5 & 2 & 1 & 3 \\
\hline 47 & 2 & 1 & 4 & 5 & 3 \\
\hline 48 & 2 & 1 & 4 & 5 & 3 \\
\hline 49 & 2 & 1 & 4 & 5 & 3 \\
\hline 50 & 2 & 1 & 4 & 5 & 3 \\
\hline 51 & 4 & 5 & 2 & 1 & 3 \\
\hline 52 & 4 & 5 & 2 & 1 & 3 \\
\hline 53 & 4 & 5 & 3 & 1 & 2 \\
\hline 54 & 2 & 1 & 3 & 5 & 4 \\
\hline 55 & 4 & 5 & 3 & 1 & 2 \\
\hline 56 & 4 & 5 & 3 & 1 & 2 \\
\hline 57 & 2 & 1 & 4 & 5 & 3 \\
\hline 58 & 4 & 5 & 2 & 1 & 3 \\
\hline 59 & 2 & 1 & 4 & 5 & 3 \\
\hline 60 & 4 & 5 & 3 & 1 & 2 \\
\hline 62 & 4 & 5 & 2 & 1 & 3 \\
\hline $\begin{array}{c}\text { SUM OF } \\
\text { RANK }\end{array}$ & 184 & 194 & 169 & 164 & 175 \\
\hline
\end{tabular}

Bol. Ciênc. Geod., sec. Artigos, Curitiba, v. 19, no 4, p.729-745, out-dez, 2013. 
The area difference in all projections are analysed with Minitab version_16. The software's graph option gives statistical parameters such as the distribution of area differences, the means and the standard deviations. The statistical analysis and results are shown in the Figure 4.

Figure 4 - Statistical nature of data used.

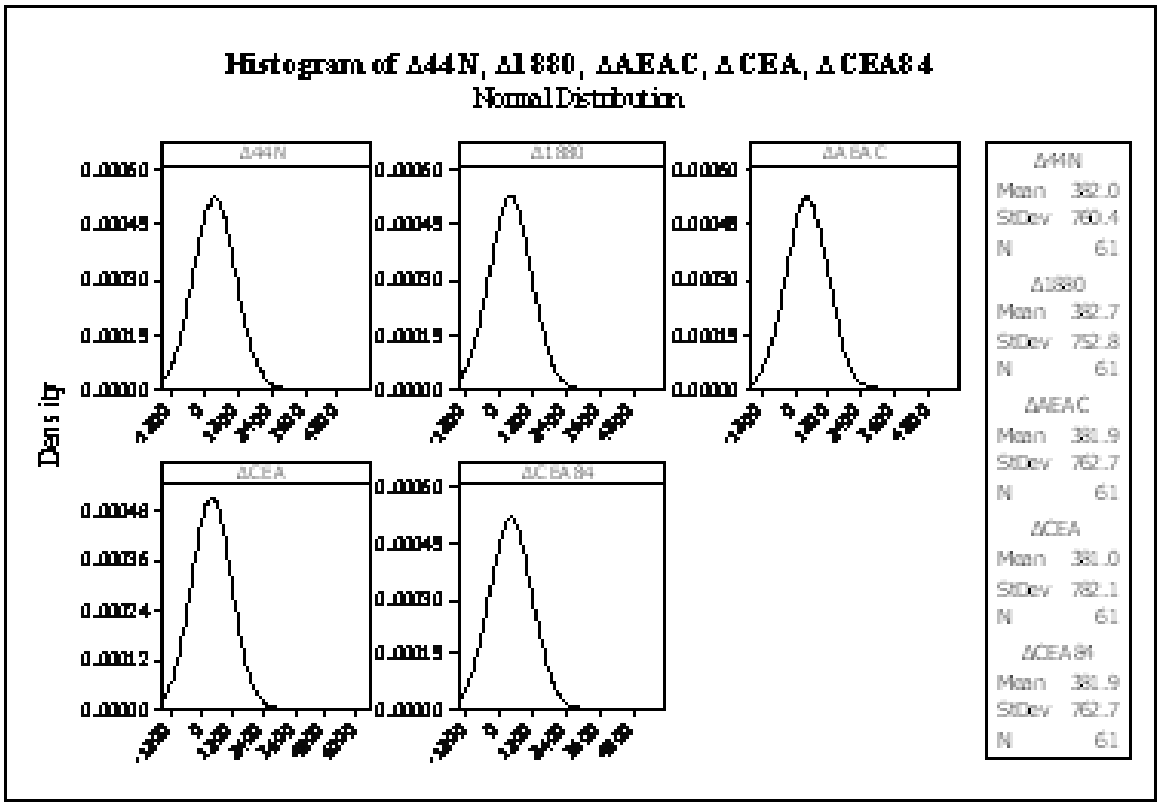

Statistics are applied to determine the nature of data used for analysis. Figure 18 shows that all data are normally distributed. The normal distribution shows that the data can be used for statistical analysis. Statistical analysis derives a relationship between a conventional chain survey and a Total Station survey. Statistical analysis helps in expanding further research based on a suitable projection.

The results show that the Cylindrical Equal Area, which is based on ellipsoid WGS-1984, and the Albers Equal Area South Asia conic have inverse ranking values near that of the of Cylindrical Equal Area, which is based on a spheroid. The projections of $44 \mathrm{~N}$ that were based on the WGS-1984 ellipsoid and Everest 1880 (IV) were found to be not suitable for projecting conventional land records. These latter projections are unable to handle terrain variations. The detailed methodology is presented as a work flow diagram in Figure 5. Details for India and the study area are elaborated below. 
Figure 5 - Work flow diagram.

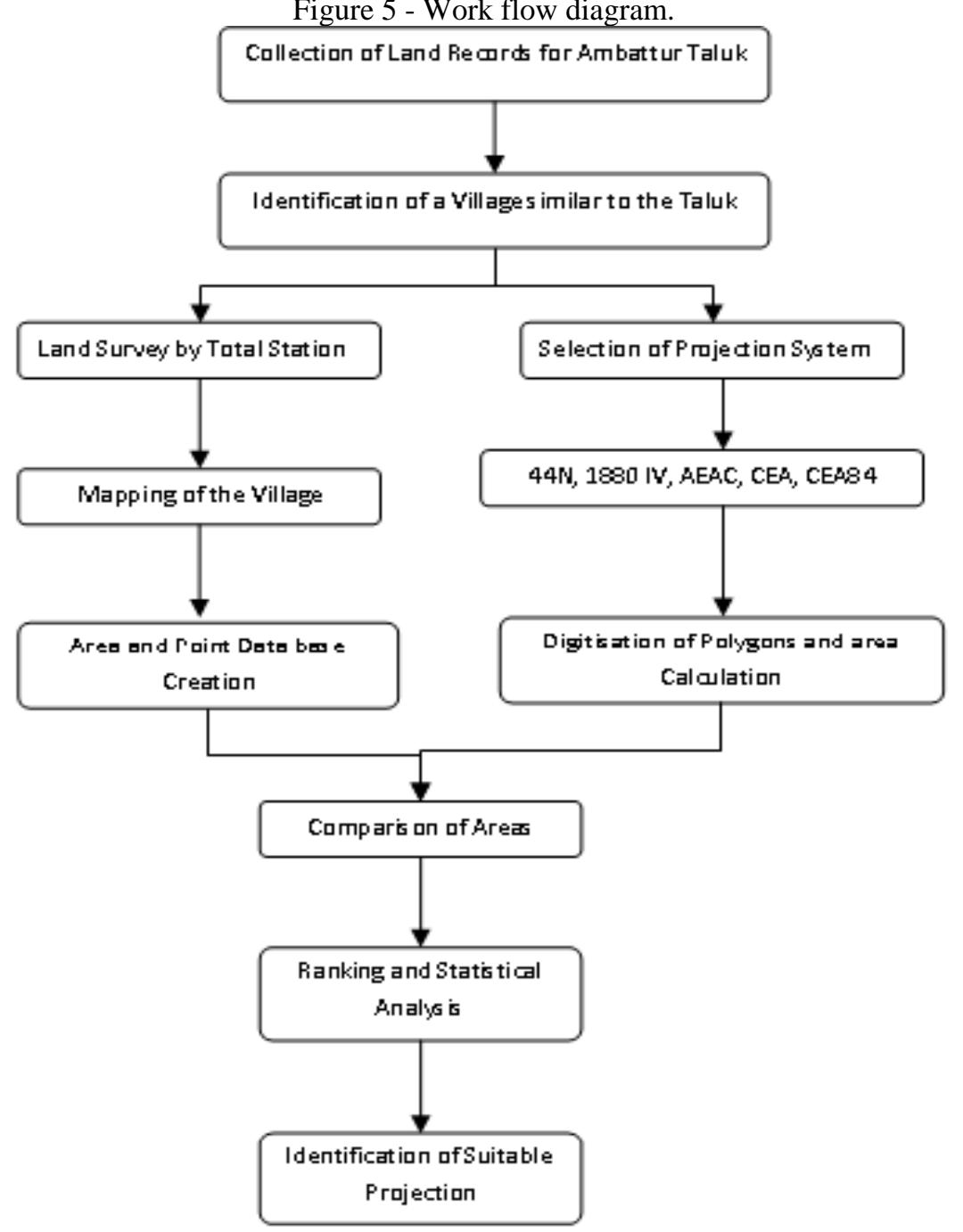

\subsection{India}

India attained independence from British colonisation on the August 15, 1947. India has emerged as one of the most rapidly developing countries in the world. The leaders of India framed the Indian Constitution, and India became a Republic on January 26, 1950. India is the largest democratic country in world. India has a land area of 2,973,190 sq km. The Land boundary extends 15,200 km while the coastal boundary spans 75,166 km including the island boundaries for Andaman, Nicobar, 
and Lakshadweep. India has 28 states and 7 union territories. The government is elected by voting by individual Indian citizens that are 18 years and above. An election is conducted once every five years for the selection of the Prime Minister of the country and the Chief Ministers of the states and Union territories. The country is administered by the Prime Minister and the ministers of the respective departments. States are administered by Chief Ministers and the ministers of the respective departments. Union territories are administered similar to states. Cadastre is administered by state governments.

The Cadastral concept was developed in India by British colonisers to aid in the collection of taxes that were imposed on property. The Cadastral System is based on the concept of cadastre. Cadastre is the collection of parcel based information to form one single record of estimated area with current information. Cadastral surveying gained importance due to the fact that it contained information of ownership and topographical features such as parcel boundaries, length, and the extent of the land.

Land as part of dynamic developmental activities is subjected to various changes. Changes in land are recorded in land records. Land records are important, and land surveying became important in developing countries. Land is surveyed as parcels. The basic unit of land in India is a land parcel. Parcels are nothing but a piece of land owned by individuals or an organisation. Details of land are recorded in the cadastral record. Maintenance of cadastral records with ownership, tax assessment, and collection of tax are carried out by officers appointed by the state government. The states of India have cadastral records concerning individual parcels. Individual parcels in town surveys are grouped in blocks. The individual parcels are grouped as village maps in rural areas.

Village maps are prepared to scales of 1 in 5000, 1 in 25,000 for states, and 1 in 50,000 for the country. The unit used for mapping is metres. Figure 6 shows India along with an inset image of the state of Tamil Nadu. On the request of the state and central government, organisations will prepare maps on required scales. Maps are computerised as a part of the land record modernisation programme. Modernisation of land surveys is also carried out. Modernisation resulted in the development of a National Spatial Data Infrastructure. The National Spatial Data Infrastructure is being developed in India to implement efficient use of land and resources. The National Spatial Data Infrastructure is formed based on the cadastral information available in the country.

Cadastral information in the state of Tamil Nadu is maintained and managed by the Tamil Nadu Survey and Land records department (PRITHVISH, 2003). Figure 7 shows a map of the state Tamil Nadu with an inset image of the Thiruvallur district. The cadastral information that was significant for selection of the study area used in this research is explained below. 
Figure 6 - India and State Tamil Nadu.

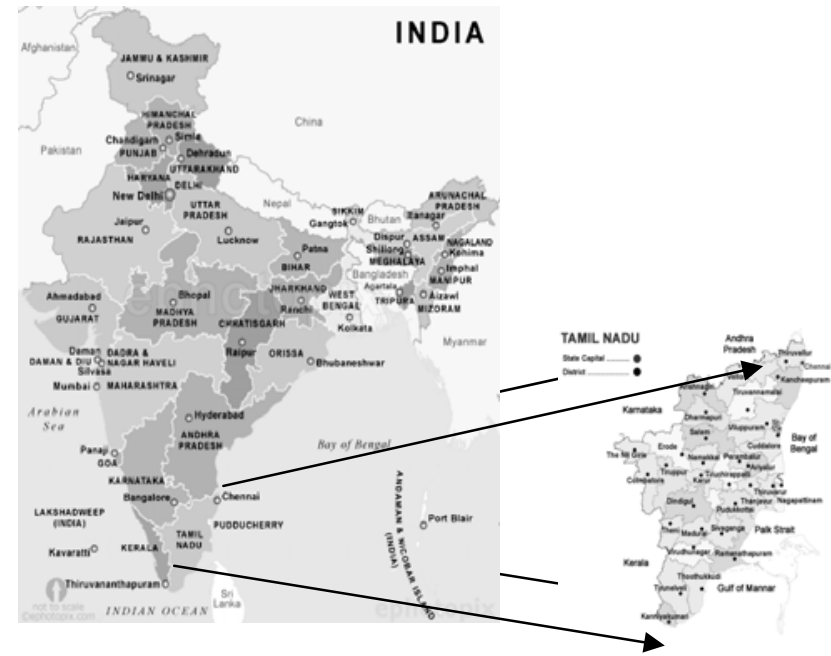

Figure 7 - State Tamil Nadu and Thiruvallur District.

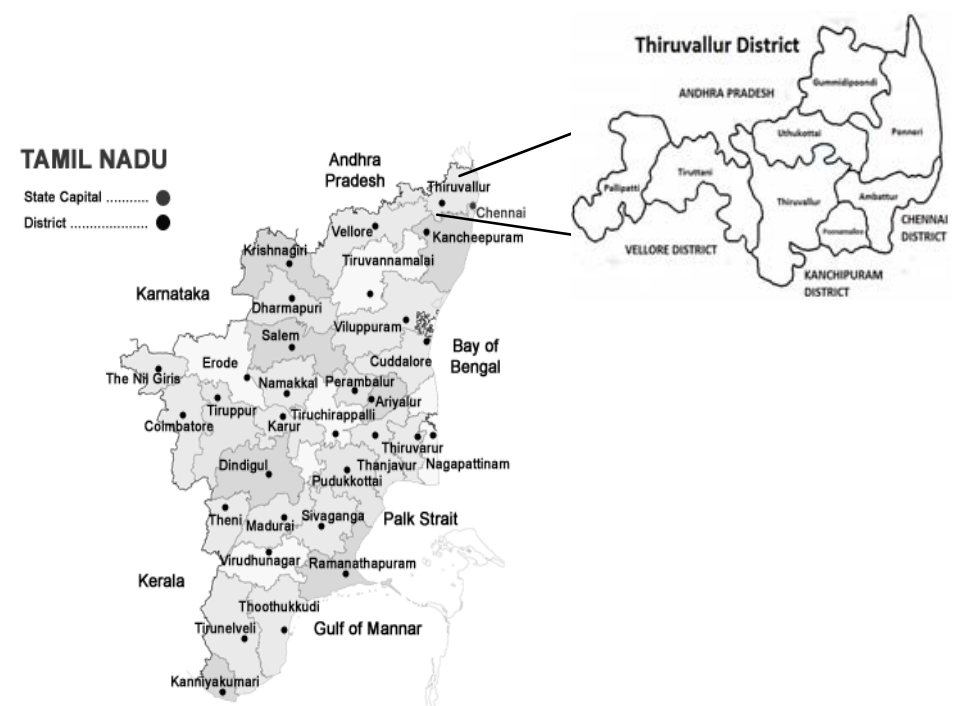

3.1.1 Study Area

The study area where the research work was carried out is Ambattur Taluk, which is near Chennai. Chennai is the capital city of the state of Tamil Nadu in India. Ambattur Taluk consists of 46 villages, out of which, 8 villages are under the administration boundary of the corporation of Chennai metropolitan city. The Bol. Ciênc. Geod., sec. Artigos, Curitiba, v. 19, nº 4, p.729-745, out-dez, 2013. 
approximate area of the study area is 49 square kilometres. The study area lies at lower left coordinates of $80^{\circ} 01^{\prime} 03^{\prime \prime} \mathrm{E}$ and $13^{\circ} 0{ }^{\prime} 56^{\prime \prime} \mathrm{N}$, and at the right top coordinates of $80^{\circ} 12^{\prime} 23^{\prime} \mathrm{E}$ and $13^{\circ} 13^{\prime} 28^{\prime \prime} \mathrm{N}$, and is shown in Figure 8 and Figure 9. Ambattur taluk was chosen for this research due to its rapid growth. The area is developed by industrialisation, suburban rail ways, expressways and infrastructure growth.

Figure 8 - Thiruvallur District and Ambattur Taluk.

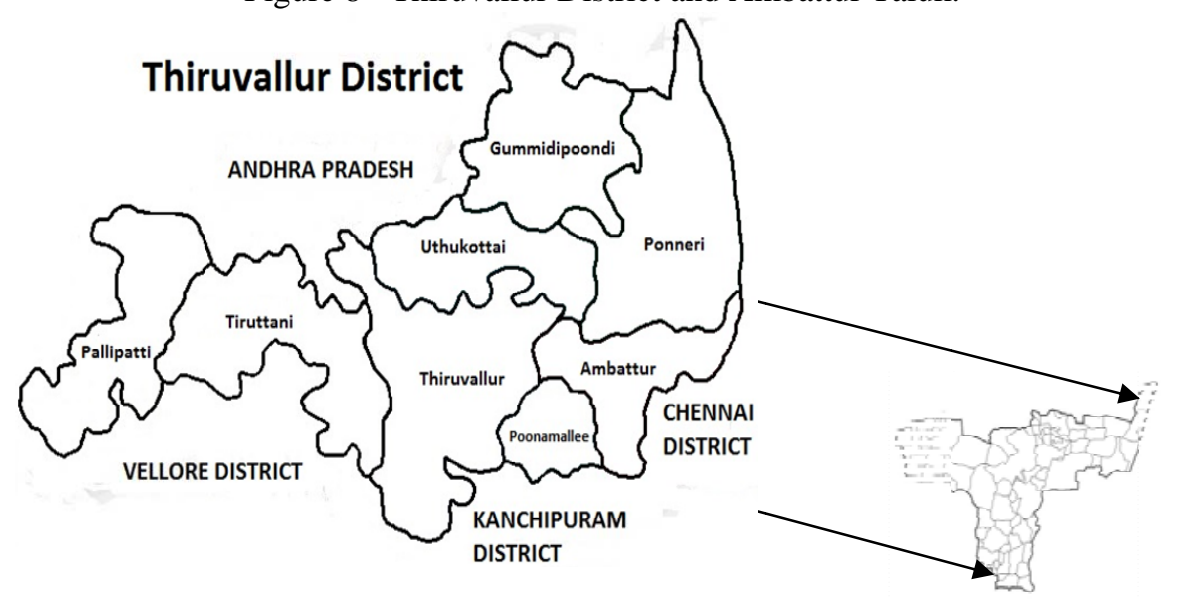

Figure 9 - Ambattur Taluk administrative boundary with 46 villages.

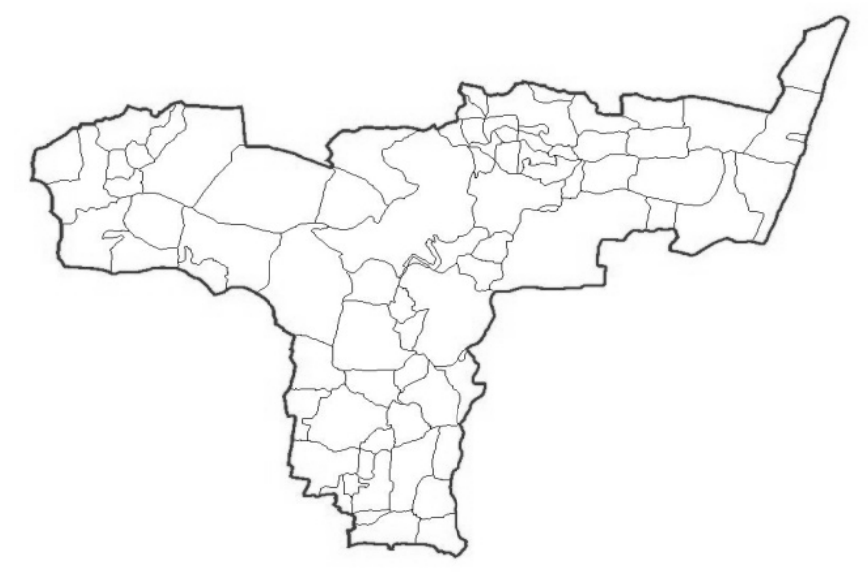

Bol. Ciênc. Geod., sec. Artigos, Curitiba, v. 19, no 4, p.729-745, out-dez, 2013. 
Figure 10 - Avadi and Ambattur railway stations.

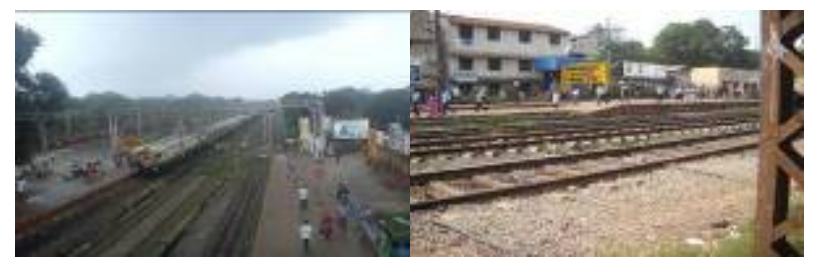

Figure 11 - AMS and Jaya Engineering Colleges.

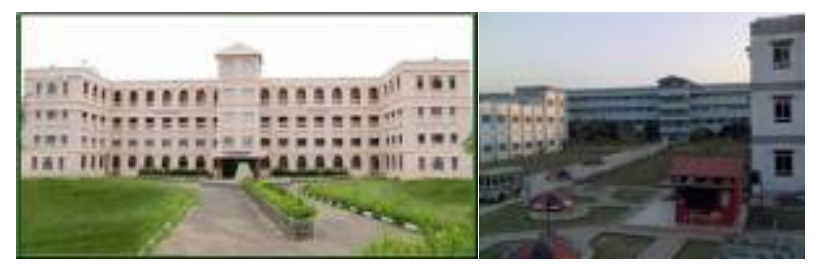

Figure 12 - Sri Krishna and VelTech Engineering Colleges.

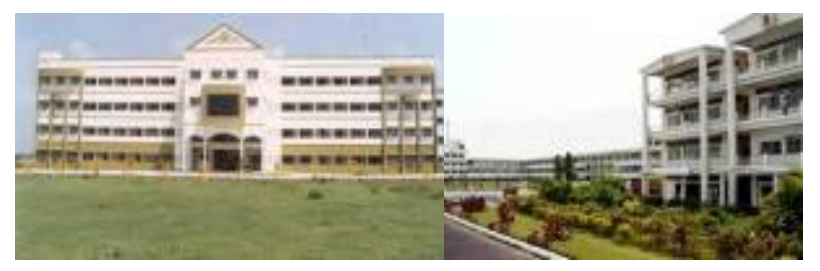

Figure 13 - Avadi and Ambattur Municipality Offices.

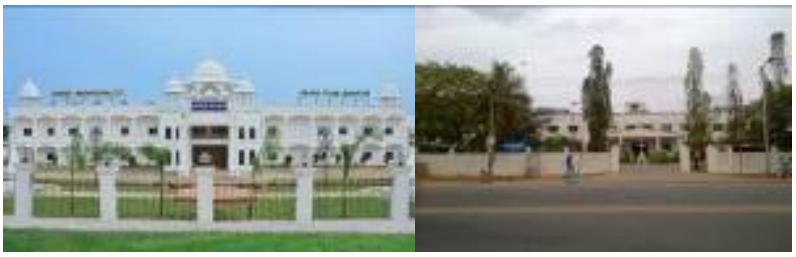

Figure 14 - Heavy Vehicles Factory Avadi.

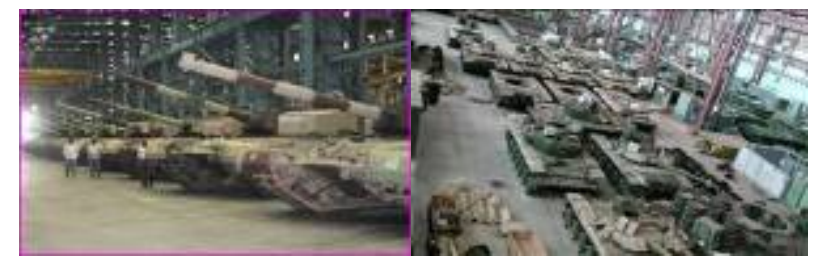

Bol. Ciênc. Geod., sec. Artigos, Curitiba, v. 19, nº 4, p.729-745, out-dez, 2013. 
Figure 15 - Sewage treatment plant and Dunlop tyre factory.

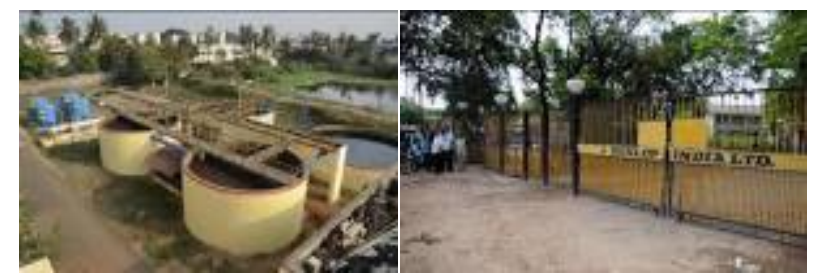

Figure 16 - Four-lane Express way.

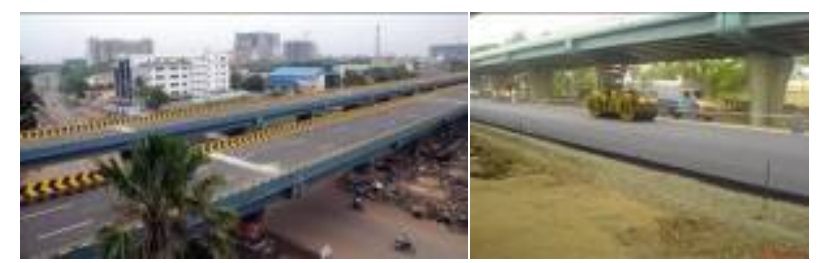

The face of Ambattur Taluk changes dynamically every day. Land in Ambattur taluk requires rapid management and maintenance due to selling, buying and transactions like renting, pledging land for loans against property, etc. Field photographs, which are shown in Figures 10 to 16, demonstrate the need for selection of an appropriate projection system. The software and survey technologies that were used to select a suitable projection system are elaborated on below.

\subsection{Materials Used}

Software Minitab16, ARC GIS 9.3, Leica Geo-office, and Auto Cad 2007 are employed in this research. Minitab 16 is a statistical software package that is used to analyse numerical data. ARC GIS 9.3 is geographical information software that is used for advanced mapping. The software is capable of storing data in different layers and acts as a decision support tool. (MAPLES, 2013). Leica Geo-Office is Global Positioning System (GPS) software that is used for processing data from GPS. Auto Cad 2007 is drafting software that is used for mapping coordinates from Total Station in this research.

Modern survey equipment using GPS and Total Station are used in this research. GPS is based on signal observations from satellites (ROBERTS, 2005). Total Station is a survey instrument that combines the functions of a field book, EDM and a digital Theodolite. The achievable level of accuracy with the Total Station used in this research is $\pm 1 \mathrm{~cm}$ in distance measured linearly and has an angular accuracy of \pm 3 ” seconds (TAE-SUC AND KANG, 1994). The use of the Total Station for development of the coordinate based cadastre was demonstrated in Milwaukee County (BAUER and FELLOW, 1994). A discussion of the results is provided below. 


\section{RESULTS}

Results show that the methodology adapted in this research provides good solutions. The solutions help us to find a suitable projection for projecting conventional village maps with minimal distortion. The data used to arrive at the solutions are analysed using statistical tools. Those tools helped us to determine the behaviour of data used for identifying projections. The most suitable projection for handling a conventional village map is the Cylindrical Equal Area, which is based on a spheroid. The projection projects a conventional village map within a chain survey error allowance. The area allowance for the error $\pm 5 \%$ is not violated by land parcels after projecting with a suitable projection. The objective of finding a suitable projection is achieved. Proper modernisation of land records could be carried out with a suitable projection. Further research regarding projections can be carried out based on new results.

\section{CONCLUSION AND DISSCUSSION}

A number of studies regarding projections and mapping have been conducted. This paper is one of them and had the goal of finding a suitable projection. Projections for conventional chain surveys created land records whit minimal errors were found. This paper is a step towards future digital land records, which are obtained from digital error adjustment of conventional land records. Digital adjustment techniques are to be developed in India. India is a developing country where the infrastructure needs must be met rapidly to allow infrastructure growth. Infrastructure growth needs land. The need for land and the global rise in the real estate industry is affecting India's real estate industry. Land costs have risen significantly, resulting in large bills for land transactions. Therefore, land needs to be maintained and managed efficaciously. The method used in this paper proves to be a successful tool for selecting a map projection. The map projection will be suitable for projecting conventional village maps.

\section{REFERENCES}

BAUER KURT W.; Fellow. Creation of Land Information System for Milwaukee County, Wisconsin. Journal of Surveying Engineering, Vol.120, No.4, 1994.

EASSIE, MAHER GERARD, REID KENNETH GC, THOMPSON JOSEPH M, TYRE COLIN J, Disscussion Paper on Land Registration: Void and Voidable Titles, Scottish Law Commission Disscussion Paper No. 125, February 2004.

Kanetkar T. P., Surveying and Levelling, Vols. I and II, United Book Corporation Pune, 1994.

KRISHNAN T. G.; RAMAKRISHNAN SS. Digital Cadastral Surveying for Land Encroachment Identification using Spatial Technologies. Geodetski list, Vol.66, No.2, 2012.

MAPLES STACEY. The Yale Map Collection. Accessed 22.07.2013 http://www. library.yale.edu/maps

Bol. Ciênc. Geod., sec. Artigos, Curitiba, v. 19, nº 4, p.729-745, out-dez, 2013. 
PRITHVISH NAG. Country Report 2003. 2003. Accessed 22.07.2013 http://www. cadastraltemplate.org/countryreport/India-25Mar2003.pdf

ROBERTS, C. GPS for cadastral surveying - practical considerations, Proceedings of SSC 2005 Spatial Intelligence, Innovation and Praxis: The National Biennial Conference of the Spatial Sciences Institute, September 2005. Spatial Sciences Institute, Melbourne.

SNYDER JOHN P. Map Projections-A Working Manual. Supersedes USGS Bulletin 1532, United States Government Printing Office, 1987. Washington.

Tae-suc; Kang. Cadastre Survey, Hyungseul Publication, pp. 229 -243, 1994.

( Recebido em março de 2013. Aceito em outubro de 2013). 